IKONOMIKA :Journal of Islamic Economics and Business

Volume 2, No I (20I7)

ISSN: 2527-3434 (PRINT) - ISSN: 2527-5I43 (ONLINE)

Page : $4 \mathrm{I}-52$

\title{
Determinan Kinerja Keuangan Bank Umum Syariah di Indonesia
}

\author{
Salman Al Parisi \\ SMART Consulting, Awardee LPDP PK $I 03$ - Magister Manajemen Syariah SB IPB \\ salman.al.farisi.tazkia@gmail.com
}

\begin{abstract}
This study aimed to know the effect of CAR, NPF, FDR, BOPO and NOM on ROA both of partially and simultaneously for year 20II-20I6. This study uses Panel Data Regression. Furthermore, Object of researchconsists oflslamic Banking in Indonesiawith annually data from 20IIto 2016. The dependent variable (Y) used in this panel datais $R O A$ and independent variables $(X)$ consist ofCAR, NPF, $F D R, B O P O$, and NOM. The results showed thatCAR, NPF and NOM have significant positive effecton $R O A$, while FDR andBOPO have significant negativeeffect on $R O A$. In addition, $C A R, N P F, F D R, B O P O$, and NOM variables have significant effect on ROA of Islamic Bankingsimultaneouslyfor 20II-20I6.
\end{abstract}

Keywords: Islamic banking,financial performance, panel regression

\begin{abstract}
Abstrak
Penelitian ini bertujuan untuk mengetahui pengaruh variabel CAR, NPF, FDR, $B O P O$ dan NOM terhadap ROA baik secara parsial maupun simultan selama tahun 20II-20I6.Penelitian ini menggunakan analisistegresi data panel. Objek penelitian terdiri dari Bank Umum Syariah di Indonesia dengan data tahunan 201 I sampai 20I6. Adapun variabel dependen $(Y)$ yang digunakan dalam data panel yaitu $R O A$ dan variabel independen $(X)$ terdiri dari CAR, NPF, FDR, BOPO, dan NOM.Hasil penelitian menunjukkan bahwa variabel- variabel yang mempengaruhi profitabilitas (ROA) BUS selama tahun 20II-20I6 yaitu CAR, NPF dan NOM berpengaruh signifikan positif terhadap ROA, sedangkan FDR, dan BOPO berpengaruh signifikan negatif terhadap $R O A$. Selain itu, variabel CAR, NPF, FDR, $B O P O$, dan NOM berpengaruh secara simultan terhadap ROA Bank Umum Syariah tahun 20II-20I6.
\end{abstract}

Kata Kunci: bank umum syariah, kinerja keuangan, regresi panel

Received: February I4, 20I7- Revised: April 30, 20I7- Accepted: Mei 20, 2017

SMART Consulting, Awardee LPDP PK I03 - Magister Manajemen Syariah SB IPB Email: salman.al.farisi.tazkia@gmail.com

DOI: I0.24042/febi.v2iI.943 


\section{A. PENDAHULUAN}

Perbankan telah menjadi tulang punggung perekonomian negara Indonesia dimana sebagai salah satu pelaku utamanya, bank mempunyai peranan penting sebagai lembaga intermediary (perantara) antara pihak yang kelebihan dana (surplus unit) yang menyimpan kelebihan dananya di bank dengan pihak yang kekurangan dana (deficit unit) yang meminjam dana ke bank. Fungsi intermediasi ini akan berjalan dengan baik jika surplus unit maupun deficit unit memiliki kepercayaan kepada bank. Berjalannya fungsi intermediasi oleh bank akan meningkatkan efisiensi dan optimalitas penggunaan dana. Dana yang dihimpun dari surplus unit oleh bank selanjutnya akan disalurkan dalam bentuk pinjaman kepada deficit unit dalam berbagai bentuk aktivitas produktif. Aktifitas produktif tersebut selanjutnya akan meningkatkan output dan menciptakan lapangan kerja yang pada akhirnya meningkatkan pendapatan dan kesejahteraan masyarakat (Muharam dan Pusvitasari, 2007).

Bank memiliki peran penting dalam perekonomian dan besarnya tingkat kepercayaan masyarakat yang harus dijaga dalam industri ini menyebabkan perbankan menjadi industri yang paling banyak dan ketat diatur. Setiap ketentuan yang dibuat di industri perbankan pada akhirnya akan bermuara pada satu tujuan, yakni menghasilkan sistem perbankan yang sehat, kuat dan stabil. Dengan demikian bank dapat menjalankan fungsi financial intermediary dengan optimal. Beberapa prinsip dapat dijadikan landasan dalam menyusun peraturan perbankan yaitu: efisiensi, keadilan sosial, pengembangan sistem, dan pemeliharaan institusi. Tujuannya adalah untuk menciptakan perbankan yang aman dan sehat (Qurniawati, 2013).

Industri perbankan sendiri telah lama mengalami kemajuan pesat di era modern ini. Kebutuhan pemerintah akan bank, terutama bank sentral, untuk mengatur dan mengawasi keadaan perekenomian negara. Sedangkan bagi individu maupun korporasi, menggunakan bank untuk menabung, investasi dan berbelanja. Berbagai kemudahan yang diberikan oleh perbankan itu mengakibatkan perubahan gaya hidup masyarakat dan cara mereka menggunakan uang.

Di Indonesia, perbankan dilakukan dalam kerangka sistem perbankan ganda dalam kerangka Arsitektur Perbankan Indonesia (API), untuk menghadirkan alternatif jasa perbankan yang semakin lengkap kepada masyarakat Indonesia. Secara bersama-sama, sistem perbankan syariah dan perbankan konvensional secara sinergis mendukung mobilisasi dana masyarakat secara lebih luas untuk meningkatkan kemampuan pembiayaan bagi sektor-sektor perekonomian nasional. 
Bank Syariah telah menjadi sebuah fenomena yang menarik di dalam perekonomian nasional. Bukan hanya karena imunitasnya yang tinggi terhadap krisis namun pula keuntungan yang menjanjikan dengan potensi pasar yang besar. Itulah sebabnya banyak negara yang berlomba-lomba untuk mendirikan bank syariah atau industri keuangan syariah dan beberapa industri konvensional pun tergiur untuk membentuk anak usaha yang berbasis syariah. Perlahan industri perbankan syariah pun terus tumbuh dan mengikuti selera masyarakat atau pasar. Seyogianya,gaya hidup seorang Muslim sesuai dengan ajaran Islam, sehingga menuntut adanya pemenuhan kebutuhan mereka akan layanan perbankan yang sesuai dengan syariah. Oleh karena itulah demi untuk menangkap pasar yang membutuhkan tersebut banyak bank syariah didirikan. Hal ini dibuktikan dengan semakin bertambah Bank Umum Syariah sampai dengan akhir tahun 2016 tercatat sebanyak I2 Bank Umum Syariah (BUS) dan 22 Unit Usaha Syariah (UUS).

\section{Gambar I.}

PerkembanganPerbankanSyariah 2008-20I4

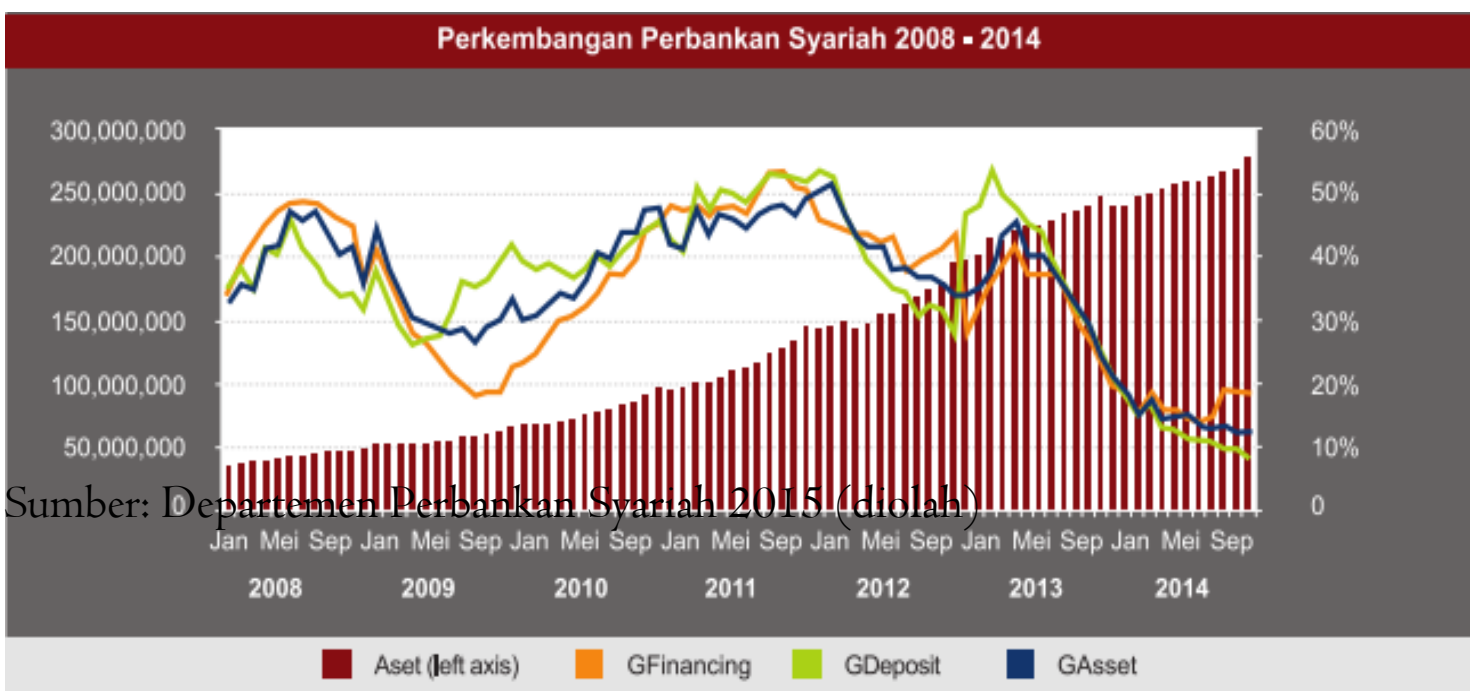

Karakteristik sistem perbankan syariah yang beroperasi berdasarkan prinsip bagi hasil memberikan alternatif sistem perbankan yang saling menguntungkan bagi masyarakat dan bank, serta menonjolkan aspek keadilan dalam bertransaksi, investasi yang beretika, mengedepankan nilai-nilai kebersamaan dan persaudaraan dalam berproduksi, dan menghindari kegiatan spekulatif dalam bertransaksi keuangan. Dengan menyediakan beragam produk serta layanan jasa perbankan yang beragam dengan skema keuangan yang lebih bervariatif, perbankan syariah menjadi alternatif sistem perbankan yang kredibel dan dapat dinimati oleh seluruh golongan 
masyarakat Indonesia tanpa terkecuali. (www.bi.go.id). Maka dari itu perbankan syariah menunjukkan perkembangannya dari tahun ke tahun.

Gambar I menjelaskan bahwa perbankan syariah nasional dalam dekade terakhir terus menunjukkan pertumbuhan yang positif dan memuaskan yang tercermin dari volume usaha yang terus tumbuh, dana investasi dan dana titipan masyarakat serta penyaluran pembiayaan yang terus meningkat. Adanya perkembangan tersebut diharapkan dapat memberikan kontribusi yang cukup penting dalam aktivitas perekonomian di Indonesia, khususnya dalam mendorong penyediaan pembiayaan kepada masyarakat sehingga dapat meningkatkan produksi dan daya beli masyarakat.

Namun demikian di tengah pertumbuhan positif industri perbankan syariah yang cukup menggembirakan tersebut dengan peningkatan rata- rata sekitar 33.2\% dalam IO tahun terakhir, terlihat adanya fenomena perlambatan pertumbuhan volume usaha dalam perkembangan di tiga tahun terakhir sehingga pada akhir tahun 2014 hanya mencatatkan pertumbuhan sebesar I2\% sebagaimana terlihat dalam grafik di atas mengenai perkembangan perbankan syariah. Hal ini diperkuat dengan kondisi perekonomian Indonesia yang sedang melesu pada tahun 2015. Perlambatan ini perlu diwaspadai dan dicermati apa saja faktor- faktor yang mempengaruhinya sehingga dengan antisipasi tersebut dapat mendukung kelancaran jasa keuangan yang sempat melambat dan meningkatkan kinerja perbankan syariah.

Kinerja yang baik adalah kinerja yang efisien, dan pada dasarnya efisiensi merupakan indikator penting dalam mengukur kinerja keseluruhan dari suatu bank. Pada awalnya, evaluasi kinerja efisiensi bank diukur dengan menggunakan rasio keuangan, seperti rasio BOPO. Nilai rasio BOPO didapat dari perbandingan antara biaya operasional dengan pendapatan operasional. Perbankan syariah perlu memperhatikan kinerja dari tahun ke tahun. Bank yang memiliki kinerja yang baik, tidak hanya dapat menjalankan fungsi intermediasi-nya saja kepada masyarakat dengan meningkatkan pembiayaan atau kredit, melainkan juga perlu memperhatikan sejauh mana tingkat NPF atau kredit macet suatu bank dari dana yang disalurkan dalam pembiayaan. Semakin tinggi NPF suatu bank, maka akan mempengaruhi profitabilitas suatu bank, yang pada akhirnya dapat mempengaruhi kinerja bank di kemudian hari. Sebagaimana Ranianti dan Ratnawati (20I4) menyatakan bahwa FDR, DPK dan NPF dapat mempengaruhi profitabilitas suatu bank. Selain itu, Syafrida dan Abror (20II) menyatakan bahwa faktor- faktor yang mempengaruhi pertumbuhan aset perbankan syariah tidak hanya berkaitan dengan tingkat NPF dan FDR nya saja, melainkan juga bagaimana tingkat efisiensi dan efektivitas jumlah kantor dan biaya promosi. 
Maka dari itu, penelitian ini akan membahas tentang analisis determinan kinerja keuangan perbankan syariah di Indonesia untuk mengetahui pengaruh CAR, NPF, FDR, BOPO, dan NOM terhadap variabel ROA (profitabilitas) baik secara parsial maupun simultan selama tahun 201I-2016.Sehingga dapat menjadi gambaran umum faktor- faktor apa saja yang mempengaruhi kondisi perbankan syariah di Indonesia saat ini yang masihmencapai 5.12 persenpangsa pasar-nya.

\section{B. METODE}

Penelitian ini menggunakan data sekunder selama periode 20I I- 2016. Data pokok tersebut dapat diperoleh dari publikasi yang diterbitkan oleh masing-masing perbankan syariah. Sampel yang digunakan dalam penelitian ini yaitu Bank Umum Syariah kecuali Bank Tabungan Pensiunan Nasional Syariah, disebabkan bank tersebut tergabung ke dalam BUS di akhir tahun 20I4. Sebelas Bank Umum Syariah tersebut terdiri dari Bank Muammalat Indonesia, Bank Victoria Syariah, Bank BRI Syariah, BJB Syariah, BNI Syariah, Bank Syariah Mandiri, Bank Syariah Mega Indonesia, Bank Panin Syariah, Bank Syariah Bukopin, BCA Syariah, dan Maybank Syariah Indonesia.

Teknik analisis penelitian ini menggunakan regresi data panel yang terdiri dari pemilihan model terbaik antara PLS, FEM, REM dan GLS disertai uji asumsi klasik dengan menggunakan software Stata I2 dan Ms. Excel untuk menganalisis pengaruh CAR, NPF, FDR, BOPO, NOMterhadap ROA Bank Umum Syariah di Indonesia. Bentuk model persamaan matematis yang digunakan dalam penelitian ini sebagai berikut:

$\mathrm{ROA}_{i t}=\alpha_{o}+\beta_{I} C A R_{i t}+\beta_{2} N P F_{i t}+\beta_{3} F D R_{i t}+\beta_{4} B O P O_{i t}+\beta_{5} N O M_{i t}+\mu_{i t}$

Di mana: ROA ialah profitabilitas; CAR ialah rasio kecukupan modal; NPF ialah rasio pembiayaan bermasalah; FDR ialah rasio pembiayaan terhadap Dana Pihak Ketiga; BOPO ialah rasio efisiensi operasional; NOM ialah rasio rentabilitas untuk mengukur kemampuan bank dalam menghasilkan laba.

\section{HASIL DAN PEMBAHASAN \\ Hasil}

Tabel I menunjukkan bahwa model terbaik adalah model FEM. Akan tetapi dalam pendekatan model pilihan terjadi gejala heteroskedastisitas dan autokorelasi. Hal ini dapat dilihat dari nilai statistik Wald test for groupwise heteroskedasticity yang signifikan pada taraf nyata I persen dan nilai statistik uji Wooldridge test for autocorrelation in panel data yang signifikan pada taraf nyata I persen. Berdasarkan Pindyck dan Rubinfeld (1998) dinyatakan bahwa pada hakikatnya, jika terjadi 
gejala heteroskedastisitas dan autokorelasi pada suatu model persamaan, maka tidak mempengaruhi validitas suatu model, artinya model tersebut masih tetap bersifat tidak bias dan konsisten, hanya saja penduga yang dihasilkan menjadi tidak efisien. Maka dari itu, untuk mengatasi kedua gejala tersebut, maka dilakukan pengujian kembali melalui pendekatan GLS (Generalized Least Square) yang dapat mengakomodasi keberadaan gejala heteroskedastisitas dan autokorelasi pada model data panel. Estimasi model dengan pendekatan GLS menunjukkan hasil yang tergolong baik dikarenakan nilai statistik uji $\mathrm{F} / \mathrm{Wald}$ ( $F /$ Wald test) yaitu sebesar 202.73 yang signifikan pada taraf nyata I persen. Hasil tersebut menjelaskan bahwa kelima variabel independen (CAR, NPF, FDR, BOPO, dan NOM) berpengaruh signifikan secara bersama-sama (simultan) terhadap variabel dependen, yaitu ROA.

Jika dilihat secara parsial per variabel independen pada model terpilih GLS, maka hasil yang ditunjukkan dari kelima variabel independen yaitu variabel CAR, NPF, FDR, BOPO dan NOM berpengaruh signifikan terhadap ROA. Berdasarkan hasil empiris pada Tabel I maka dapat diperoleh model regresi panel data sebagai berikut:

$\mathrm{ROA}_{\text {it }}=9, \mathrm{I} 20+0,034 \mathrm{CAR}_{\mathrm{it}}+0,206 \mathrm{NPF}_{\text {it }}-0,018 \mathrm{FDR}_{\text {it }}-0,084 \mathrm{BOPO}_{\text {it }}+$ $0,055 \mathrm{NOM}_{\mathrm{it}}$

Berdasarkan model regresi tersebut dapat dijelaskan bahwa nilai $\alpha$ sebesar 9,I20 menunjukkan bahwa jika variabel independen dalam model penelitian ini sama dengan nol maka besarnya Return on Asset (ROA) akan konstan yaitu sebesar 9,I20 satuan. Nilai $\beta_{1}$ sebesar 0,034 menunjukkan bahwa setiap penambahan satuan variabel CAR, sementara variabel NPF, FDR, BOPO dan NOM tidak mengalami perubahan (tetap) maka ROA akan mengalami peningkatan sebesar 0,034 satuan. Hal ini berarti CAR berpengaruh signifikan positif terhadap ROA Bank Umum Syariah.

Tabel. I

Hasil Ekonometrika

\begin{tabular}{|c|c|c|c|c|}
\hline Koefisien & PLS & FEM & REM & GLS \\
\hline \multicolumn{5}{|l|}{$\operatorname{ROA}(\mathrm{Y})$} \\
\hline Constant & $\begin{array}{l}9.120^{2} \\
(0.000)\end{array}$ & $\begin{array}{l}9.244^{2} \\
(0.000)\end{array}$ & $\begin{array}{l}9.428^{x} \\
(0.000)\end{array}$ & $\begin{array}{l}9.120^{2} \\
(0.000)\end{array}$ \\
\hline $\mathrm{CAR}_{\mathrm{it}}$ & $\begin{array}{l}0.034^{x} \\
(0.024)\end{array}$ & $\begin{array}{l}0.033^{3} \\
(0.099)\end{array}$ & $\begin{array}{l}0.03 I^{2} \\
(0.043)\end{array}$ & $\begin{array}{l}0.034 \\
(0.015)\end{array}$ \\
\hline $\mathrm{NPF}_{\text {it }}$ & $\begin{array}{l}0.206^{2} \\
(0.000)\end{array}$ & $\begin{array}{l}0.258^{(0.000)} \\
(0.000\end{array}$ & $\begin{array}{l}0.229^{4} \\
(0.000)\end{array}$ & $\begin{array}{l}0.206 \\
(0.000)\end{array}$ \\
\hline
\end{tabular}




\begin{tabular}{|c|c|c|c|c|}
\hline FDR $_{\text {it }}$ & $\begin{array}{l}-0.018^{-1} \\
(0.006)\end{array}$ & $\begin{array}{l}-0.0 \mathrm{II} \\
(0.108)\end{array}$ & $\begin{array}{l}-0.016^{\text {wat }} \\
(0.012)\end{array}$ & $\begin{array}{l}-0.018 \\
(0.003)\end{array}$ \\
\hline $\mathrm{BOPO}_{\text {it }}$ & $\begin{array}{l}-0.084^{x} \\
(0.000)\end{array}$ & $\begin{array}{l}-0.095^{(0.000)} \\
(0)\end{array}$ & $\begin{array}{l}-0.09 I^{4} \\
(0.000)\end{array}$ & $\begin{array}{l}-0.084^{2} \\
(0.000)\end{array}$ \\
\hline $\mathrm{NOM}_{\mathrm{it}}$ & $\begin{array}{l}0.055^{x} \\
(0.022)\end{array}$ & $\begin{array}{l}0.057^{2} \\
(0.009)\end{array}$ & $\begin{array}{l}0.057 \\
(0.008)\end{array}$ & $\begin{array}{l}0.055^{2} \\
(0.014)\end{array}$ \\
\hline $\mathrm{R}^{2}$ & 0.754 & 0.854 & 0.852 & - \\
\hline F/ Wald Test & $\begin{array}{l}36.86^{2} \\
(0.0000)\end{array}$ & $\begin{array}{l}58.74 \\
(0.0003)\end{array}$ & $\begin{array}{l}257.05^{2} \\
(0.0000)\end{array}$ & $\begin{array}{l}202.73 \\
(0.0000)\end{array}$ \\
\hline Chow- F Test & & & & $\begin{array}{l}36.86^{2} \\
(0.0000)\end{array}$ \\
\hline Hausman Test & & & & $\begin{array}{l}\text { I0.24 } \\
(0.0686)\end{array}$ \\
\hline LM Test & & & & $\begin{array}{l}\mathrm{I} 4.24 \\
(0.000 \mathrm{I})\end{array}$ \\
\hline $\begin{array}{l}\text { Modified Wald test } \\
\text { for groupwise } \\
\text { heteroskedasticity }\end{array}$ & & & & $\begin{array}{l}3012.94 \\
(0.0000)\end{array}$ \\
\hline $\begin{array}{l}\text { Wooldridge test for } \\
\text { autocorrelation }\end{array}$ & & & & $\begin{array}{l}17.593^{3} \\
(0.0018)\end{array}$ \\
\hline
\end{tabular}

Keterangan : Signifikan pada taraf I\%, Signifikan pada taraf 5\%,

${ }^{*}$ Signifikan pada taraf 10\%

Dengan demikian, hubungan antara CAR dan ROA menunjukkan hubungan yang searah (positif). Artinya, setiap kenaikan CAR maka diduga dapat meningkatkan ROA. Sebaliknya setiap penurunan CAR maka diduga dapat menurunkan ROA.Nilai $\beta_{2}$ sebesar 0,206 menunjukkan bahwa setiap penambahan satuan variabel NPF, sementara variabel CAR, FDR, BOPO dan NOM tidak mengalami perubahan (tetap) maka ROA akan mengalami peningkatan sebesar 0,206 satuan. Hal ini menandakan bahwa NPF berpengaruh signifikan positif terhadap ROA Bank Umum Syariah. Dengan demikian, hubungan antara NPF dan ROA menunjukkan hubungan yang searah (positif). Oleh karenanya, setiap kenaikan NPF maka diduga dapat meningkatkan ROA. Sebaliknya, setiap penurunan NPF maka diduga dapat menurunkan ROA. 
Nilai $\beta_{3}$ sebesar $-0,018$ menunjukkan bahwa setiap penambahan satuan variabel FDR, sementara variabel $\mathrm{CAR}, \mathrm{NPF}, \mathrm{BOPO}$ dan NOM tidak mengalami perubahan (tetap) maka ROA akan mengalami penurunan sebesar 0,0I8 satuan. Hal ini berarti FDR berpengaruh signifikan negatif terhadap ROA Bank Umum Syariah.Dengan demikian, hubungan antara FDR dan ROA menunjukkan hubungan yang tidak searah (negatif). Artinya, setiap kenaikan FDR maka diduga dapat menurunkan ROA. Sebaliknya setiap penurunan FDR maka diduga dapat menaikkan ROA.Nilai $\beta_{4}$ sebesar -0,084 menunjukkan bahwa setiap penambahan satuan variabel $\mathrm{BOPO}$, sementara variabel CAR, NPF, FDR dan NOM tidak mengalami perubahan (tetap) maka ROA akan mengalami penurunan sebesar 0,084 satuan. Oleh karenanya, BOPO berpengaruh signifikan negatif terhadap ROA Bank Umum Syariah. Dengan demikian, hubungan antara BOPO dan ROA menunjukkan hubungan yang tidak searah (negatif). Hal ini menandakan bahwa setiap kenaikan BOPO maka diduga dapat menurunkan ROA. Sebaliknya, setiap penurunan $\mathrm{BOPO}$ maka diduga dapat menaikkan ROA.

Nilai $\beta_{5}$ sebesar 0,055 menunjukkan bahwa setiap penambahan satuan variabel NOM, sementara variabel CAR, FDR, BOPO dan NPF tidak mengalami perubahan (tetap) maka ROA akan mengalami peningkatan sebesar 0,055 satuan. Hal ini berarti NOM berpengaruh signifikan positif terhadap ROA Bank Umum Syariah. Dengan demikian, hubungan antara NOM dan ROA menunjukkan hubungan yang searah (positif). Oleh karenanya, setiap kenaikan NOM maka diduga dapat meningkatkan ROA. Sebaliknya, setiap penurunan NOM maka diduga dapat menurunkan ROA.

\section{Pembahasan}

Untuk menghitung rasio permodalan digunakan Kewajiban Penyediaan Modal Minimum (KPMM). Hasil penelitian ini menunjukkan bahwa variabel CAR berpengaruh signifikan positif terhadap ROA BUS. Berpengaruhnya CAR terhadap ROA diduga karena BUS dapat mengoptimalkan modal yang ada selama periode tersebut. Hasil estimasi model ini sesuai dengan konsep dan logika operasi bank, dan teori likuiditas bank. CAR yang tinggi menunjukkan bahwa modal bank semakin besar, sehingga bank dapat melakukan ekspansi pembiayaan. Selain itu kepercayaan masyarakat terhadap bank juga diduga dapat meningkat, karena jaminan dana masyarakat semakin tinggi. Dengan bertambahnya modal bank dan bertambahnya kepercayaan masyarakat terhadap bank, maka bank dapat melakukan ekspansi pembiayaan untuk meningkatkan pendapatan operasionalnya.Penelitian ini didukung oleh Merkusiwati (2007), Sudiyatno \& Suroso (2010), Werdaningtyas (2002) yang menyimpulkan bahwa CAR berpengaruh positif terhadap ROA. 
Peningkatan pada NPF akan mengakibatkan pertumbuhan total aset mengalami penurunan. NPF mencerminkan risiko pembiayaan (kredit), semakin kecil NPF maka semakin kecil pula risiko pembiayaan (kredit) yang ditanggung oleh bank (Nusantara, 2009). Hasil penelitian ini menunjukkan bahwa variabel NPF berpengaruh signifikan positif terhadap ROA Bank Umum Syariah. Hasil tersebut berbeda dengan teori pada umumnya. Berdasarkan kriteria yang telah ditetapkan oleh Bank Indonesia yang termasuk dengan NPF adalah pembiayaan kurang lancar, pembiayaan diragukan dan pembiayaan macet. Salah satu resiko usaha bank menurut peraturan Bank Indonesia adalah resiko kredit yang didefinisikan sebagai resiko yang timbul akibat kegagalan counterparty memenuhi kewajiban. Tidak terpenuhinya kewajiban nasabah kepada bank menyebabkan bank menderita kerugian dengan tidak diterimanya penerimaan yang sebelumnya sudah diperkirakan (Susilo, 2000). Hasil penelitian ini sama dengan Harianto (2017), namun berbeda dengan penelitian Hutasuhut (2009) Ranianti \& Ratnawati (20I4) dan Sabir, dkk (20I2) yang menyatakan bahwa NPF memiliki pengaruh negatif terhadap ROA (profitabilitas).

FDR memberikangambaran optimalisasi bank syariah untuk mengembangkan sektor riil, karena semakin besar FDR artinya semakin optimal bank syariah dalam menyalurkan DPK yang ada pada bank dalam bentuk pembiayaan bagi sektor riil. Hasil penelitian ini menunjukkan bahwa variabel FDR berpengaruh signifikan negatif terhadap ROA Bank Umum Syariah. Hasil penelitian ini tidak berbanding lurus dengan hipotesis awal dimana jika FDR meningkat, maka seharusnya ROA pun meningkat. Hasil penelitian yang menunjukkan bahwa FDR berpengaruh negatif terhadap ROA diduga karena Bank Umum Syariah mengalami resiko pembiayaan kurang lancar oleh nasabahnya. Hal ini dibuktikan oleh tingkat rata- rata NPF Bank Umum Syariah yang mengalami peningkatan hingga $4.04 \%$ di tahun $20 \mathrm{I} 4 \mathrm{dan}$ di atas $6.64 \%$ pada akhir tahun 2015. Sebagaimana penelitian Fauzi (2015) bahwa FDR memiliki pengaruh negatif terhadap ROA tetapi tidak signifikan. Bank Umum Syariah diharapkan dapat menjaga besaran variabel FDRantara 80\% - IIO\% sesuai dengan standar yang digunakan oleh Bank Indonesia dan perlu memperhatikan dan mempertimbangkan kondisi perekonomian terkini yang belum membaik.Selain itu, perbankan syariah harus mau melakukan linkage dengan Lembaga Keuangan Mikro Syariah (LKMS) yang memiliki fleksibilitas dan local knowledge dalam memperkuat pembiayaan usaha mikro, kecil dan menengah (UMKM).

Hasil penelitian ini menunjukkan bahwa variabel $\mathrm{BOPO}$ berpengaruh signifikan negatif terhadap ROA pada Bank Umum Syariah. Hasil penelitian ini 
sesuai dengan teori, BOPO yang tinggi diduga dapat menurunkan ROA Bank Umum Syariah karena inefisien. Semakin kecil BOPO menunjukkan semakin efisien bank dalam menjalankan aktifitas usahanya, $\mathrm{BOPO}$ yang kecil menunjukkan bahwa biaya operasional bank lebih kecil dari pendapatan operasionalnya sehingga hal tersebut menunjukkan bahwa manajemen bank sangat efisien dalam menjalankan aktivitas operasionalnya. Hasil penelitian ini senadadengan Setiawan (2009), Dasih (20I4) dan Sabir, dkk (2012), yang menyatakan bahwa BOPO berpengaruh signifikan negatif terhadap ROA.

Hasil penelitian ini menunjukkan bahwa variabel NOM berpengaruh signifikan positif terhadap ROA Bank Umum Syariah. Hasil penelitian ini berbanding lurus dengan hipotesis awal dimana jika pendapatan operasional bersih meningkat, maka dapat meningkatkan ROA Bank Umum Syariah. Selain itu, disebabkan oleh tren bank syariah yang cenderungmenunjukkan perkembangan selama periode penelitian. Perbankan syariah perlu memperhatikan tercapainya trend positif pada pendapatan operasional bersih, sehingga dapat meningkatkan bargaining position perbankan syariah di tengah masyarakat Indonesia yang mayoritas Muslim.Pada akhir 2016 tercatat bahwa pertumbuhan perbankan syariah mencapai 19,67 persen.Dan pangsa pasar perbankan syariah mencapai angka 5,I2 persen. Hasil ini menunjukkan peningkatan dari periode sebelumnya, tetapi relatif belum signifikan (Sakti, 20I7).

\section{SIMPULAN}

Berdasarkan analisis model GLS dari penelitian ini, maka dapat disimpulkan bahwa CAR, NPF, FDR, BOPO, dan NOM berpengaruh secara simultan terhadap ROA Bank Umum Syariah tahun 20II-20I6. Adapun secara parsial, CAR, NPF dan NOM berpengaruh signifikan positif terhadap profitabilitas (ROA) BUS selama tahun 20II-20I6, sedangkan FDR dan BOPO berpengaruh signifikan negatif terhadap ROA Bank Umum Syariah. Hasil penelitian ini berimplikasi bahwa Bank Umum Syariah di Indonesia perlu memperhatikan antara keseimbangan fungsi intermediasi bank dan kesehatan bank yaitu meningkatkan pembiayaan (FDR) kepada sektor riil seperti sektor UMKM. Di samping itu, perlu diperhatikan juga masalah risiko gagal bayarnasabah dari dana pembiayaan dengan manajemen sistem bank yang baik, sehingga dapat meningkatkan ROA Bank Umum Syariah secara optimal. Hal ini pada akhirnya akan berdampak pada kinerja keuangan BUS secara komprehensif dan meningkatkan trustmasyarakat Indonesia terhadap perbankan syariah yang baru mencapai pangsa pasar sebesar 5,12 persen pada perekonomian Indonesia di akhir tahun 2016. 
Dalam penelitian ini, terdapat keterbatasan data yang hanya dapat menggunakan sebelas Bank Umum Syariah, tidak memasukkan Bank Tabungan Pensiunan Nasional Syariah (BTPNS). Hal ini disebabkan BTPNS baru bergabung menjadi Bank Umum Syariah di akhir tahun 2014 sehingga tidak ada data tahun sebelumnya. Oleh karena itu, perlu adanya penelitian lebih lanjut terkait penelitian ini dengan menggunakan metode analisis lain yang dapat menghasilkan data yang lebih komprehensif.

\section{PUSTAKA ACUAN}

Dasih, K. (20I4). Pengaruh Rasio Keuangan Terhadap ROA Perbankan (Studi Pada Bank Umum yang Terdaftar di BEI 2007-2013). (Skripsi Tidak Dipublikasikan). Yogyakarta:Universitas Negeri Yogyakarta.

Fauzi, K.A. (2015). Analisis Pengaruh Tingkat Kesehatan Bank, Pembiayaan Bermasalah dan Tingkat Likuiditas Terhadap Kinerja Keuangan BUS Periode 20I0-20I4. (Skripsi Tidak Diterbitkan). Yogyakarta: UIN Sunan Kalijaga.

Harianto, S. (20I7). Rasio Keuangan dan Pengaruhnya Terhadap Profitabilitas Pada Bank Pembiayaan Rakyat Syariah. Esensi: Jurnal Bisnis dan Manajemen. Vol. 7 (I): 4I-48.

Hutasuhut, D.R. (2009). Pengaruh FDR, BOPO dan NPF Terhadap Profitabilitas Perbankan Syariah di Indonesia.(Skripsi Tidak Dipublikasikan). Medan: Universitas Sumatera Utara.

Merkusiwati, N.K.L.A. (2007). Evaluasi Pengaruh CAMEL Terhadap Kinerja Perusahaan. Buletin Studi Ekonomi, Vol. I2(I): I03-I24.

Muharam, H dan Pusvitasari, R. (2007). Analisis Perbandingan Efisiensi Bank Syariah di Indonesia Dengan Metode Data Envelopment Analysis Periode Tahun 2005. Jurnal Ekonomi dan Bisnis Islam, II (3): 80-I66.

Nusantara, A.B. (2009). Analisis Pengaruh NPL, CAR, LDR, dan BOPO Terhadap Profitabilitas Bank (Perbandingan Bank Umum Go Publik dan Bank Umum Non Go Publik di Indonesia Periode Tahun 2005- 2007). (Tesis Tidak Dipublikasikan). Semarang: Universitas Diponegoro.

Pindyck, R S. dan Rubinfeld, D L. (1998). Econometric Models and Economic Forecasts, $4^{\text {th }}$ Edition. Singapore: McGraw Hill.

Qurniawati, R.S. (2013). Efisiensi Perbankan Di Indonesia Dan Pengaruhnya Terhadap Return Saham Dengan Pendekatan Data Envelopment Analysis (DEA),BENEFIT Jurnal Manajemen dan Bisnis, Vol.I7(I): 27-40. 
Ranianti, A. dan Ratnawati, N. (20I4). Pengaruh Pembiayaan, DPK, NPF Terhadap ROA Perbankan Syariah di Indonesia 2009-2013: Penerapan Model Simultan.Jurnal Ekonomi Pembangunan.Vol. I(2): I09-I28.

Sabir, M., dkk. (2012). Pengaruh Rasio Kesehatan Bank Terhadap Kinerja Keuangan Bank Umum Syariah dan Bank Konvensional di Indonesia.Jurnal Analisis, Vol. I(I): 79-86.

Setiawan, A. (2009). Analisis Pengaruh Faktor Makroekonomi, Pangsa Pasar dan Karakteristik Bank Terhadap Profitabilitas Bank Syariah (Studi Pada Bank Syariah Periode 2005-2008). (Tesis Tidak Dipublikasikan). Semarang: Universitas Diponegoro.

Sudiyatno, B. dan Suroso, J. (2010). Analisis Pengaruh Dana Pihak Ketiga, BOPO, CAR dan LDR Terhadap Kinerja Keuangan Pada Sektor Perbankan yang Go Public di Bursa Efek Indonesia (BEI) (Periode 2005-2008).Jurnal Dinamika Keuangan dan Perbankan, Vol. 2 (2): I25-I37.

Susilo, S. (2000). Bank dan Lembaga Keuangan Lainnya. Jakarta: Salemba Empat. Syafrida, Idan Abror, A. (20II). Faktor-Faktor Internal dan Eksternal yang Mempengaruhi Pertumbuhan Aset Perbankan Syariah di Indonesia.Jurnal Ekonomi dan Bisnis Vol. I0 (I): I9-24.

Werdaningtyas, H.(2002). Faktor yang Mempengaruhi Profitabilitas Bank Take over Pra-merger di Indonesia.Jurnal Manajemen Indonesia. Vol. I (2): 2439. 